\title{
Do patients with diabetes use the insulin pen properly?
}

\author{
Betul Tosun ${ }^{1}$, Fatma Ilknur Cinar², Zeliha Topcu ${ }^{3}$, Burcu Masatoglu ${ }^{4}$, Nurten Ozen ${ }^{5}$, \\ Gulcan Bagcivan ${ }^{6}$, Ozge Kilic ${ }^{7}$, Canan Demirci ${ }^{7}$, Ayten Altunbas ${ }^{7}$, Alper Sonmez ${ }^{7}$
}

1. Hasan Kalyoncu University, Faculty of Health Sciences, Gaziantep, Turkey.

2. University of Health Sciences, Gulhane Faculty of Nursing, Ankara, Turkey.

3. Mechanized Infantry Brigade, 1st Stage Health Inspection Center, Mardin, Turkey.

4. University of Health Sciences, Sisli Hamidiye Etfal Training and Research Hospital, Istanbul, Turkey.

5. Istinye University, Faculty of Health Science, Istanbul, Turkey.

6. Koç University, School of Nursing, Istanbul, Turkey.

7. University of Health Sciences, Gulhane Training and Research Hospital, Department of Endocrinology and Metabolism Disease, Ankara, Turkey.

\begin{abstract}
Aim: This study was conducted to evaluate the insulin pen application knowledge and skills of patients with diabetes.

Methods: In our descriptive study, 200 patients with diabetes were asked to present the insulin pen injection technique on a mannequin and the steps of the pen injection implementation were noted on the data collection form as correct/incorrect by researchers.

Results: More than 3 out of 4 (79.5\%) of the participants were using the insulin pen or the cartridge after the expiry date, $70.5 \%$ were not rotating the injection site, and $63.0 \%$ were massaging the skin after injection. Injection sites complications were significantly more in those who were using the insulin pen or the cartridge after the expiry date, those who don't know the proper length of the needle and the possible body injection sites, those who don't rotate the injection sites, those who massage after injection, and those who don't use a new needle at each injection $(\mathrm{p}<0.05)$.

Conclusion: This study put into light some failures in the knowledge and skills of patients with diabetes regarding insulin pen use. Nurses should provide patients with diabetes an effective and repetitive training concerning insulin pen use.

Keywords: Diabetes, insulin injection, insulin pen, patient knowledge.

DOI: https://dx.doi.org/10.4314/ahs.v19i1.38

Cite as: Tosun B, Cinar FI, Topсu Z, Masatoglu B, Ozen N, Bagcivan G, et al. Dopatients with diabetes use the insulin pen properly? Afri Health Sci. 2019;19(1). 1628-1637. bttps://dx.doi.org/10.4314/abs.v19i1.38
\end{abstract}

\section{Introduction}

Diabetes mellitus is one of the largest global health emergencies of the $21^{\text {st }}$ century ${ }^{1}$. Worldwide, the frequency of diabetes among $20-79$ years aged adults was $6.4 \%(285$ million individuals) in 2010 and it is estimated to be $7.7 \%$ (439 million individuals) in 2030. In the United States,

\section{Corresponding author: \\ Betul Tosun, Hasan Kalyoncu University, Faculty of Health Sciences, Gaziantep, Turkey. \\ Email: tosunbetul@gmail.com}

$9.3 \%$ of the population (29.1 million individuals) had diabetes in 2014 and it is projected to increase by $54 \%$ between 2015 and 2030. Also, in Turkey the prevalence of diabetes is $13.7 \%$ and a significant proportion of our community is candidate for diabetes due to obesity and prediabetes $^{2,3}$. Individuals with diabetes bear a higher risk for life-threatening medical problems compared to individuals without diabetes. Continuous higher glycaemia may cause serious disorders affecting heart, blood vessels, eye, kidney and nerves. Moreover, individuals with diabetes are at increased risk for infection development. Complications of diabetes can be avoided with controlled glycaemia, blood pressure and cholesterol as close to normal as possible ${ }^{4,5}$. In order to keep the complications un- 
der control and the quality of life satisfactory, patients with diabetes should be provided continuous medical and nursing care, and training on self-management. The main goal of treatment of diabetes is achieving a proper glycemic control, thereby minimizing the incidence of complications ${ }^{5-7}$.

In maintaining a proper metabolic control, insulin therapy has a key role not only for patients with type 1 diabetes, but also for patients with type 2 diabetes ${ }^{7}$. Ready insulin pen is preferred by physicians and patients because of its easiness to use and safeness in dosage regulation ${ }^{8,9}$. However, deficient injection techniques, such as repetitive use of insulin pen needle and not rotating the injection site, may hamper a successive glycemic control and requires attention $^{10,11}$. Literature review on patients with diabetes show that there are common errors on insulin pen use such as, preferring the same anatomical site for injection, not implementing the pinch up method correctly, using the pen needle multiple times, not performing rotations, etc. $^{12,13}$ If attention is not devoted, patients may experience complications such as hypoglycemia, bleeding, ecchymosis and lipodystrophy on the injection site. Therefore, patients should be equipped with knowledge and skills to avoid these complications and benefit from the treatment ${ }^{13-16}$.

There are descriptive studies which assess the attitudes of patients on insulin pen use by enquiries ${ }^{16-19}$ but the studies that use observation of insulin injection as a tool of assessment in patients who self-administer insulin pen are limited ${ }^{19,20}$. There are no studies assessing the proper injection of insulin with insulin pen, and the effectiveness of patient education by simulation. Given the fact that nearly $25 \%$ of medical expenses in Turkey arise from diabetes and diabetes related illnesses ${ }^{5}$, control of diabetes bears a significant importance. Despite the decisive role of proper injection technique in achieving the optimal effect of insulin injection, it is rarely an attention payed and neglected step ${ }^{14,21}$. Incorrect injection technique is one of the barriers to intended glycemic control ${ }^{19,22}$. Therefore, the supervision of injection technique during the follow-up of patient by nurse is important to achieve a successive insulin treatment. The aim of this study was to evaluate the insulin pen injection knowledge and skills of patients with diabetes.

\section{Methods \\ Study design and participants}

This descriptive study was conducted in the Department of Endocrinology and Metabolism out-patient clinic in a training hospital between January and June 2015 in Ankara, Turkey.

The eligibility criteria for the patients were: (1) being 18 years of age or older; (2) being diagnosed with type 1 and/or 2 diabetes and not pregnant; (3) being a volunteer, and (4) being prescribed 1 or more of the disposable insulin pens for a minimum of 8 weeks. The criterion of eight weeks insulin pen use was chosen to observe the alteration in HbA1c levels. Red blood cells in the human body survive for 8-12 weeks before renewal, HbA1c can be used to reflect average blood glucose levels over that duration, providing a useful longer-term gauge of blood glucose control ${ }^{5}$.

During the data collection period, 232 patients with diabetes visited the out-patient clinic in 6 months. $32 \mathrm{pa}-$ tients were excluded due to not being able to volunteer to participate in the study $(n=14)$, using insulin pen for less than 8 weeks $(n=8)$, and not being able to self-administer the insulin pen $(n=10)$. Consequently, 200 patients who met the research criteria and were willing to participate were enrolled in this study.

\section{Ethical considerations}

Ethical approval, which agreed with the principles in the Declaration of Helsinki (2013), was obtained by the local university institutional review board (Document Number: 50687469-1491-61-14/16484-99). Patient signed informed consent before data collection. After data collection, the patients who were incorrectly implementing the steps of insulin injection were trained by the researchers and steps were repeated on a mannequin until the erroneous implementation is corrected.

\section{Measurement instruments}

Socio-demographic and medical backgrounds of patients were asked using the "socio-demographic and clinical characteristics form" and the insulin pen using techniques steps were checked with the "insulin pen injection technique checklist". 
Socio-demographic and clinical characteristics form This form, comprise of socio-demographic questions and data related to diabetes, was developed by the researchers in light of medical literature ${ }^{12,19,20}$. The socio-demographic data comprised of age, gender, marital status, educational status, employment status, exercise and smoking. Diabetes-related data included; type, duration of diabetes, duration of insulin therapy, difficulty in injection, daily insulin injection times. Researchers also questioned presence of hypertension and dyslipidemia of patients.

The HbA1c and other parameters were collected from the patients' medical records that existed for last 3 months. The body mass index (BMI) was calculated based on height and weight $\left[\mathrm{BMI}=\right.$ weight $(\mathrm{kg}) /\left(\text { height }(\mathrm{m})^{2}\right]^{23}$.

Injection sites on patient's body were checked with observation and palpation for (1) lipodystrophy (lipohypertrophy, lipoatrophy), (2) bleeding and/or (3)bruise; the presence of at least one of them was accepted as a complication $^{10,15,24,25}$.

\section{Insulin pen injection technique checklist}

This checklist comprises the rules or informations that related to insulin pen injection developed based on the disposable insulin pen manufacturer instructional guidelines and articles referencing insulin injection technique and storage $\mathrm{e}^{10,26}$. The checklist comprises 19 items under 3 main section (Table 2). The sections were: (1) Preparation and Knowledge about Insulin Pen, (2) Site of Injection and Tissue, and (3) Using Devices and Injection Technique. Patients' injection skills and their knowledge with regard to insulin injection were assessed with this form.

\section{Data collection procedure}

In our department of endocrinology and metabolism out-patient clinic, insulin pen prescribed patients with diabetes are called for routine control visit at regular intervals by the physician, unless there is an emergency. When the patients with diabetes are prescribed insulin pen, they are trained on diabetes and insulin pen use by nurses. In the control visit, as a part of our study, after obtaining the signed consent, patients were asked to show how they inject the insulin on a mannequin without the researcher nurse's interference in the out-patient education room. Patients were observed during the insulin pen injection and their knowledge on the issue was assessed with reference to the Insulin pen injection technique checklist by the researchers. After injection practice on the model, patients' body was examined to evaluate if there were any injection complications in the injection sides on their body.

During the observation, the researcher nurse was assessing the patients' knowledge about the number of injections per day, needle length, the injection sites, whether the skin fold technique and rotation was being used, needle entry angle, the time the needle remains under skin, needle reuse, how to pull out the needle after injection, and the storage conditions. Each step of insulin pen injection was marked on the checklist as "correct" or "incorrect" by research nurse. The questions that could not be presented by patients on a mannequin were verbally asked to patients.

\section{Data analysis}

SPSS for Windows 15.0 (SPSS Inc., Chicago, IL., USA) package program was used for the data analysis. Data on descriptive statistics were presented in number, percentage and mean \pm standard deviation. "Correct/incorrect" steps on the insulin pen injection checklist and categorical variables were compared using a Chi-square test. $\mathrm{p}<0.05$ was accepted as statistically significant.

\section{Results}

The mean age of the participant was $59.91 \pm 11.29$ (min: 23-max: 86) years. More than half of participants were female $(59.0 \%), 77.0 \%$ were married, and $63.6 \%$ were primary school graduate. The majority of the participants $(88.5 \%)$ had type 2 diabetes and mean duration of diabetes was $12.77 \pm 7.36$ years. The Socio-demographic and clinical characteristics of participants are presented in Table 1. 
Table 1. Socio-demographic and clinical characteristics of patients $(n=200)$.

\begin{tabular}{|c|c|}
\hline Characteristics & n $(\%)$ \\
\hline Age (years) $($ mean \pm SD) & $59.91 \pm 11.29$ \\
\hline \multicolumn{2}{|l|}{ Gender } \\
\hline Female & $118(59.0)$ \\
\hline Male & $82(41.0)$ \\
\hline \multicolumn{2}{|l|}{ Marital status } \\
\hline Married & $154(77.0)$ \\
\hline Single & $46(23.0)$ \\
\hline \multicolumn{2}{|l|}{ Educational status } \\
\hline Primary school or less & $126(63.0)$ \\
\hline High School & $57(28.5)$ \\
\hline University graduate or more & $17(8.5)$ \\
\hline \multicolumn{2}{|l|}{ Employment status } \\
\hline Employed & $24(12.0)$ \\
\hline Unemployed & $94(47.0)$ \\
\hline Retired & $82(41.0)$ \\
\hline \multicolumn{2}{|l|}{ Smoking } \\
\hline Yes & $17(8.5)$ \\
\hline No & $183(91.5)$ \\
\hline \multicolumn{2}{|l|}{ Hypertension } \\
\hline Yes & $90(40.0)$ \\
\hline No & $110(60.0)$ \\
\hline \multicolumn{2}{|l|}{ Dyslipidemia } \\
\hline Yes & $191(95.5)$ \\
\hline No & $9(4.5)$ \\
\hline \multicolumn{2}{|l|}{ Type of diabetes } \\
\hline Type 1 & $23(11.5)$ \\
\hline Type 2 & $177(88.5)$ \\
\hline Disease duration (years) $($ mean \pm SD) & $12.77 \pm 7.36$ \\
\hline Duration of insulin therapy (years) (mean \pm SD) & $7.56 \pm 6.00$ \\
\hline \multicolumn{2}{|l|}{ Difficulty in injection } \\
\hline Yes & $167(83.5)$ \\
\hline No & $33(16.5)$ \\
\hline HbA1c (\%) $($ mean \pm SD) & $10.48 \pm 1.78$ \\
\hline BMI $\left(\mathrm{kg} / \mathrm{m}^{2}\right)(\operatorname{mean} \pm \mathrm{SD})$ & $31.86 \pm 6.14$ \\
\hline \multicolumn{2}{|l|}{ Regular exercise } \\
\hline Yes & $76(38.0)$ \\
\hline No & $124(62.0)$ \\
\hline \multicolumn{2}{|l|}{ Daily insulin injection } \\
\hline $1-2$ times & $72(36.0)$ \\
\hline 3-4 times & $128(64.0)$ \\
\hline
\end{tabular}

Data have been presented as n (\%) or mean \pm standard deviation. HbA1C, Glycosylated hemoglobin A1C; BMI, Body mass index.

With regard to the participants' insulin pen injection techniques, the most correct steps or knowledge were keeping the insulin pen in the same angle during injection (99.5\%), grasping the injection site in the right position while injecting $(98.5 \%)$, keeping the spare cartridge or insulin pen in the refrigerator $(97.0 \%)$, correctly setting the prescribed dosage $(96.5 \%)$ and penetrating the skin with a right needle angle. Also the most incorrect steps or knowledge were using the insulin pen or the cartridge after the expiry date $(79.5 \%)$, not rotating the injection site $(70.5 \%)$, massaging the skin after injection (63.0\%) and ejecting the excess air away before each injection (56.5\%) (Table 2.). 
Table 2. Evaluation of insulin pen using techniques of the participants' $(n=200)$

\begin{tabular}{|c|c|c|}
\hline Questions & $\begin{array}{l}\text { Correct } \\
\text { n }(\%)\end{array}$ & $\begin{array}{c}\text { Incorrect } \\
\text { n (\%) }\end{array}$ \\
\hline \multicolumn{3}{|l|}{ Preparation and Knowledge About Insulin Pen } \\
\hline Q1. Disposing the insulin pen or cartridge after expiry date even if it is not empty. & $41(20.5)$ & $159(79.5)$ \\
\hline Q2. Knowing the length of the needle. & $79(39.5)$ & $121(60.5)$ \\
\hline $\begin{array}{l}\text { Q3. Keeping the insulin pen and the spare cartridge in the right storage bag when } \\
\text { travelling. }\end{array}$ & $165(82.5)$ & $35(17.5)$ \\
\hline Q4. Keeping the insulin in the right storage conditions currently. & $165(82.5)$ & $35(17.5)$ \\
\hline $\begin{array}{l}\text { Q5. Keeping the insulin in the refrigerator at } 2-8^{\circ} \mathrm{C} \text { when room temperature is } \\
\text { over } 28^{\circ} \mathrm{C} \text { (in summer). }\end{array}$ & $167(83.5)$ & $33(16.5)$ \\
\hline $\begin{array}{l}\text { Q6. Keeping the spare cartridge or insulin pen in the refrigerator. } \\
\text { Site of Injection and Tissue }\end{array}$ & $194(97.0)$ & $6(3.0)$ \\
\hline Q7. Knowing the body injection sites. & $142(71.0)$ & $58(29.0)$ \\
\hline Q8. Rotating the injection sites. & $59(29.5)$ & $141(70.5)$ \\
\hline Q9. Grasping the injection site in the right position when injecting. & $197(98.5)$ & $3(1.3)$ \\
\hline Q10. Not massaging the skin after injection. & $74(37.0)$ & $126(63.0)$ \\
\hline \multicolumn{3}{|l|}{ Using Devices and Injection Technique } \\
\hline Q11. Able to change the cartridge when required. & $185(92.5)$ & $15(7.5)$ \\
\hline Q12. Using a new needle for each injection. & $98(49.0)$ & $102(51.0)$ \\
\hline Q13. Ejecting the excess air away before each injection. & $87(43.5)$ & $113(56.5)$ \\
\hline Q14. Ejecting the excess air in the injector correctly. & $91(45.5)$ & $109(54.5)$ \\
\hline Q15. Correctly setting the prescribed dosage. & $193(96.5)$ & $7(3.5)$ \\
\hline $\begin{array}{l}\text { Q16. Penetrating the skin with a right needle angle, and keeping it in the same } \\
\text { angle during injection. }\end{array}$ & $199(99.5)$ & $1(0.5)$ \\
\hline Q17. After penetrating the skin, pushing the injector piston correctly. & $198(99.0)$ & $2(1.0)$ \\
\hline Q18. After injection, counting to ten before removing the needle. & $115(57.5)$ & $85(42.5)$ \\
\hline Q19. Removing the needle with same penetration angle. & $196(98.0)$ & $4(2.0)$ \\
\hline
\end{tabular}

“Q” Question.

It was found that complications related to insulin injection were statistically more significant in participants who were using the insulin pen or the cartridge after the expiry date $(\mathrm{x} 2=4.500 ; \mathrm{p}=0.034)$, who did not know the proper length of the needle $(\mathrm{x} 2=10.880 ; \mathrm{p}=0.001)$ and the possible body injection sites $(\mathrm{x} 2=3.310 ; \mathrm{p}=0.049)$, who didnot rotate the injection sites $(\mathrm{x} 2=7.698 ; \mathrm{p}=0.006)$, who massaged the skin after injection $(\mathrm{x} 2=6.056 ; \mathrm{p}=$ $0.013)$, and who did not use a new needle at each injection $(\mathrm{x} 2=10.305 ; \mathrm{p}=0.001)$ (Table 3). 
Table 3. Comparison of insulin pen using skills (correct/incorrect) and complications on the injection site $(n=200)$

\begin{tabular}{|c|c|c|c|c|c|c|}
\hline \multicolumn{7}{|c|}{ Insulin Pen Using Skills } \\
\hline \multirow{3}{*}{ Questions } & \multirow{2}{*}{\multicolumn{2}{|c|}{$\frac{\text { Correct }}{\text { Complication }}$}} & \multirow{2}{*}{\multicolumn{2}{|c|}{$\begin{array}{c}\text { Incorrect } \\
\text { Complication }\end{array}$}} & \multirow{3}{*}{$x^{2}$} & \multirow{3}{*}{$p$} \\
\hline & & & & & & \\
\hline & $\begin{array}{c}\text { Yes } \\
\mathrm{n}(\%)\end{array}$ & $\begin{array}{c}\text { No } \\
\mathrm{n}(\%)\end{array}$ & $\begin{array}{c}\text { Yes } \\
\mathrm{n}(\%)\end{array}$ & $\begin{array}{c}\text { No } \\
\mathrm{n}(\%)\end{array}$ & & \\
\hline $\begin{array}{l}\text { Preparation and Knowledge About Insulin Pen } \\
\text { Q1. Disposing the insulin pen or cartridge after expiry } \\
\text { date even if it is not empty. }\end{array}$ & $\begin{array}{c}30 \\
(73.2)\end{array}$ & $\begin{array}{c}11 \\
(26.8)\end{array}$ & $\begin{array}{c}138 \\
(86.8)\end{array}$ & $\begin{array}{c}21 \\
(13.2)\end{array}$ & 4.500 & $0.034 *$ \\
\hline Q2. Knowing the length of the needle. & $\begin{array}{c}58 \\
(73.4)\end{array}$ & $\begin{array}{c}21 \\
(26.6)\end{array}$ & $\begin{array}{c}110 \\
(90.9)\end{array}$ & $11(9.1)$ & 10.880 & $0.001 *$ \\
\hline $\begin{array}{l}\text { Q3. Keeping the insulin pen and the spare cartridge in } \\
\text { the right storage bag when travelling. }\end{array}$ & $\begin{array}{l}138 \\
(83.6)\end{array}$ & $\begin{array}{c}27 \\
(16.4)\end{array}$ & $\begin{array}{c}30 \\
(85.7)\end{array}$ & $5(17.5)$ & 0.093 & 0.761 \\
\hline $\begin{array}{l}\text { Q4. Keeping the insulin in the right storage conditions } \\
\text { currently. }\end{array}$ & $\begin{array}{c}136 \\
(82.4)\end{array}$ & $\begin{array}{c}29 \\
(17.6)\end{array}$ & $(91.4)$ & $3(8.6)$ & 1.742 & 0.187 \\
\hline $\begin{array}{l}\text { Q5. Keeping the insulin in the refrigerator at } 2-8^{\circ} \mathrm{C} \\
\text { when room temperature is over } 28^{\circ} \mathrm{C} \text { (in summer). }\end{array}$ & $\begin{array}{c}139 \\
(83.2)\end{array}$ & $\begin{array}{c}28 \\
(16.8)\end{array}$ & $\begin{array}{c}29 \\
(87.9)\end{array}$ & $4(12.1)$ & 0.442 & 0.506 \\
\hline $\begin{array}{l}\text { Q6. Keeping the spare cartridge or insulin pen in the } \\
\text { refrigerator. } \\
\text { Site of Injection and Tissue }\end{array}$ & $\begin{array}{c}163 \\
(84.0)\end{array}$ & $\begin{array}{c}31 \\
(16.0)\end{array}$ & $\begin{array}{c}5 \\
(83.3)\end{array}$ & $1(16.7)$ & 0.002 & 0.964 \\
\hline Q7. Knowing the body injection sites. & $\begin{array}{c}115 \\
(81.0)\end{array}$ & $\begin{array}{c}27 \\
(19.0)\end{array}$ & $\begin{array}{c}53 \\
(91.4)\end{array}$ & $5(9.6)$ & 3.310 & $0.049 *$ \\
\hline Q8. Rotating the injection sites. & $\begin{array}{c}43 \\
(72.9)\end{array}$ & $16(27.1)$ & $\begin{array}{l}125 \\
(88.7)\end{array}$ & $\begin{array}{c}16 \\
(11.3)\end{array}$ & 7.698 & $0.006^{*}$ \\
\hline $\begin{array}{l}\text { Q9. Grasping the injection site in the right position } \\
\text { when injecting. }\end{array}$ & $\begin{array}{c}165 \\
(83.8)\end{array}$ & $\begin{array}{c}32 \\
(16.2)\end{array}$ & $\begin{array}{c}3 \\
(100.0)\end{array}$ & - & 0.580 & 0.446 \\
\hline Q10. Not massaging the skin after injection. & $\begin{array}{c}56 \\
(75.7)\end{array}$ & $\begin{array}{c}18 \\
(24.3)\end{array}$ & $\begin{array}{c}112 \\
(88.9)\end{array}$ & $\begin{array}{c}14 \\
(11.1)\end{array}$ & 6.056 & $0.013 *$ \\
\hline Using Devices and Injection Technique & & & & & & \\
\hline Q11. Able to change the cartridge when required. & $\begin{array}{c}154 \\
(83.2)\end{array}$ & $\begin{array}{c}31 \\
(16.8)\end{array}$ & $\begin{array}{c}14 \\
(93.3)\end{array}$ & $1(6.7)$ & 1.051 & 0.305 \\
\hline Q12. Using a new needle for each injection. & $\begin{array}{c}74 \\
(75.5)\end{array}$ & $\begin{array}{c}24 \\
(24.5)\end{array}$ & $\begin{array}{c}94 \\
(92.2)\end{array}$ & $8(7.8)$ & 10.305 & $0.001 *$ \\
\hline $\begin{array}{l}\text { Q13. Ejecting the excess air away before each } \\
\text { injection. }\end{array}$ & $\begin{array}{c}69 \\
(79.3)\end{array}$ & $\begin{array}{l}18 \\
(20.7)\end{array}$ & $\begin{array}{c}99 \\
(87.6)\end{array}$ & $\begin{array}{c}14 \\
(12.4)\end{array}$ & 2.520 & 0.112 \\
\hline Q14. Ejecting the excess air in the injector correctly. & $\begin{array}{c}74 \\
(81.3)\end{array}$ & $\begin{array}{c}17 \\
(18.7)\end{array}$ & $\begin{array}{c}94 \\
(86.2)\end{array}$ & $\begin{array}{c}15 \\
(13.8)\end{array}$ & 0.893 & 0.345 \\
\hline Q15. Correctly setting the prescribed dosage. & $\begin{array}{c}162 \\
(83.9)\end{array}$ & $\begin{array}{c}31 \\
(16.1)\end{array}$ & $\begin{array}{c}6 \\
(85.7)\end{array}$ & $1(14.3)$ & 0.016 & 0.900 \\
\hline $\begin{array}{l}\text { Q16. Penetrating the skin with a right needle angle, } \\
\text { and keeping it in the same angle during injection. }\end{array}$ & $\begin{array}{c}167 \\
(83.9)\end{array}$ & $\begin{array}{c}32 \\
(16.1)\end{array}$ & $\begin{array}{c}1 \\
(100.0)\end{array}$ & - & 0.191 & 0.662 \\
\hline $\begin{array}{l}\text { Q17. After penetrating the skin, pushing the injector } \\
\text { piston correctly. }\end{array}$ & $\begin{array}{c}166 \\
(83.8)\end{array}$ & $\begin{array}{c}32 \\
(16.2)\end{array}$ & $\begin{array}{c}2 \\
(100.0)\end{array}$ & - & 0.385 & 0.535 \\
\hline $\begin{array}{l}\text { Q18. After injection, counting to ten before removing } \\
\text { the needle. }\end{array}$ & $\begin{array}{c}93 \\
(80.9)\end{array}$ & $\begin{array}{c}22 \\
(19.1)\end{array}$ & $\begin{array}{c}75 \\
(88.2)\end{array}$ & $10(11.8)$ & 1.973 & 0.160 \\
\hline $\begin{array}{l}\text { Q19. Removing the needle with same penetration } \\
\text { angle. }\end{array}$ & $\begin{array}{c}165 \\
(84.2)\end{array}$ & $\begin{array}{c}31 \\
(15.8)\end{array}$ & $\begin{array}{c}3 \\
(75.0)\end{array}$ & $1(25.0)$ & 0.246 & 0.620 \\
\hline
\end{tabular}

(*), $p<0.05$ statically significant. $x^{2}$, Pearson Chi-Square Test or Fisher Exact Test for some cells have expected count less than 5 
In addition, frequency of having complications related to insulin injection on the injection side was statistically significantly higher in participants who were unemployed $(p=0.023)$, low educational status $(p=0.034)$, long-term insulin user $(\mathrm{p}=0.015)$, experiencing difficulties in injection $(p=0.001)$, not exercising regularly $(p=0.007)$, and having more than two daily injections ( $p=0.028$ ) (not shown in the table).

\section{Discussion}

This is one of the limited studies that have evaluated the insulin pen injection knowledge and skills of patients with diabetes. The results of this study showed that the majority of the patients with diabetes were keeping the spare cartridge or insulin pen in the refrigerator, grasping the injection site in the right position while injecting, correctly setting the prescribed dosage and penetrating the skin with a right needle angle, and keeping it in the same angle during injection. On the other hand, the majority of the patients were not disposing the insulin pen after the expiry date, not rotating the injection sites or massaging the skin after injection, not using a new needle for each injection.

Subcutaneous tissue is preferred for insulin injection because of the predictable absorption rate that allows a better glycemic control ${ }^{14,18,26}$. A less deep injection in the intradermal tissue may result in absorption at unpredictable rates, leakage and allergic reactions. Also because of the rich blood flow to the muscle, the risk of the insulin to be absorbed faster increases in intramuscular injection, which may lead to hypoglycemia and glycemic variations. Moreover, intramuscular injections are more painful and may result in bruises ${ }^{14}$. These reasons require patients to know the length of the needle, properly grasp the injection site, and inject in the correct location. However, in this study population, $60.5 \%$ did not know the length of the needle and most of them had complications. Patients using short needles such as $4 \mathrm{~mm}, 5 \mathrm{~mm}$ and 6 $\mathrm{mm}$ should not lift the skin and inject at a $90^{\circ}$ angle $\mathrm{e}^{14,18}$. Moreover, massaging the skin after insulin injection may result in increased blood circulation on the injection site leading insulin to be absorbed very fast, ${ }^{10,21}$ increased tissue damage on the skin and in subcutaneous layer due to injection trauma, subcutaneous bleeding and bruising ${ }^{24,27}$. Likewise, in this study it was found that the complication frequency was more in patients massaging after insulin injection.
One of the key points to be focused on is using a new needle for each injection. If the needle is not removed from the pen between two injections, air may leak into the injector causing wrong dose insulin injection. The injection should be given directly to the skin, because the needle can be blunt when administered through clothing and increase the risk of bleeding, bruising and infection ${ }^{14}$, ${ }^{17,20}$. Reusing the needle may result in distortion, bending and loss of lubrication. This can lacerate the $\operatorname{skin}^{28}$ and cause painful injections ${ }^{29}$. Ji and $\mathrm{Lou}^{12}$ reported that pen needle reuse was quite high in their study and this finding increased the risk of lipohypertrophy. Böhler et al. ${ }^{30}$ found that only $40 \%$ of their study population was using a new needle for each injection. Likewise, Mitchell et al. ${ }^{16}$ reported that one fifth of their population was keeping the needle attached on the pen, and $80 \%$ of them were removing the needle from the pen after at least three injections. Only half of the patients in this study were using a new needle for each injection. This number is very disappointing and requires special attention at patient education.

The correct rotation of injection sites is the strongest protective factor against the development of lipohypertrophy; ${ }^{10,12}$ Most of the participants in this study $(70.5 \%)$ were not rotating the injection site moreover one of the complications such as lipodystrophy, bleeding and bruising was observed in patients who were not rotating regularly and massaging after injection. Similar to our results, several studies reported that high rate of not rotating the injection side and not controlling the skin for complications in patient with diabetes. In addition, all these studies reported that lipodystrophy occurred more frequent in patients with diabetes who did not rotate injection sites $^{31,32}$.

The results of this study showed that frequency of having complications related to insulin injection was statistically significantly higher in participants who were longterm insulin user, experiencing difficulties in injection, having more than two daily injections. Our findings suggest that as long as the duration of insulin treatment and the numbers of daily injections increase, poorer injection techniques are adopted.Poor injection technique causes complications and unsatisfactory glycemic control ${ }^{11,22}$. Patients may have forgotten the correct injection technique or neglected some of the steps over time. Therefore, not only the initial patient education on insulin pen 
use given by healthcare professionals is important, but also repetitive controls are important for a successful treatment protocol ${ }^{19}$. One of the major benefits of this study is having the opportunity to determine the erroneous steps of insulin injection and difficulties experienced by patients. This may shape the patient education and follow-up visits by focusing on the erroneous steps.

In the light of our findings, nurses should be focused on common erroneous topics when caring for patients who use insulin pen injector. We suggest that knowing which steps bear a difficulty for patients and nurses, in which errors are common, may help focusing and adjusting the education program and therefore improving the effectiveness and quality of education. Diabetes nurses should inform the patients and explain the effects of massaging the skin after insulin injection and keep patients away from massaging. Patients should be educated on how to make rotation, the importance of rotation and not using the area that lipohypertrophy occurred until the tissue gets normal, and they should be examined during each visit. Furthermore, they should be equipped with knowledge and skills to self-examine the injection sites on their body by inspection and palpation.

\section{Limitations}

This study was conducted on patients with diabetes in a tertiary training and research hospital. Therefore, our results may not be generalized to patients who are admitted to and may not have sufficient support and service at primary or secondary health care facilities. In addition, it should be stated that the patients knew that they were being observed so they may have done some steps correctly.

\section{Conclusion}

It is important to train the patients who start insulin injection therapy on injection techniques and control the steps of administration on follow-up visits. Healthcare professionals have the responsibility to equip the patients with adequate knowledge, skills and competence. The insulin injection skills of patients with diabetes were poor, and the incidence of complications was high in this study. As the duration of insulin therapy gets longer and the numbers of daily injections increase, incidence of complications on the injection site increases. Improved education in optimal insulin injection technique, especially focused on reducing needle reuse, correct rotation of injection sites and not massaging the skin after injection, should be emphasized.

\section{Conflict of interest}

No conflict of interest is declared.

\section{Funding}

The authors have no support or funding to report.

\section{References}

1. International Diabetes Federation (IDF). Diabetes Atlas (2015). (7th ed.). [Cited 27 Mar 2017.] Available from URL: http://www.diabetesatlas.org/resources/2015-atlas.html

2. Türkiye Diyabet Programı 2015-2020, Sağlık Bakanlı̆̆1 Yayınları, Ankara. 2014:47-49. [Cited 20 July 2018] Available from URL: https://www.diyabetimben.com/turkiye-diyabet-programi-2015-2020/

3. Cunningham S A, Patel S A, Beckles G L, Geiss L S, Mehta N, Xie $H$, et al. County-level contextual factors associated with diabetes incidence in the United States. Annals of Epidemiology. 2018; 28:20-25 PubMed. DOI: https://doi.org/10.1016/j.annepidem.2017.11.002

4. Satman I, Omer B, Tutuncu Y, Kalaca S, Gedik S, Dinccag N, et al. Twelve-year trends in the prevalence and risk factors of diabetes and prediabetes in Turkish adults. European Journal of Epidemiology. 2013; 28:169-180. DOI: http://10.1007/s10654-013-9771-5

5. American Diabetes Association (ADA), Glycemic Targets: Standards of Medical Care in Diabetes-2018. Diabetes Care. 2018;41(Suppl. 1):55-64. DOI:https://doi. org/10.2337/dc18-S006

6. American Association of Diabetes Educators. Teaching Injection Technique to People with Diabetes (2013). [Cited 27 Mar 2017.] Available from URL: https://www. diabeteseducator.org/docs/default-source/legacydocs/_ resources/pdf/research/injectioneducationpracticeguide 7. Celik S, Cosansu G, Erdogan S, Kahraman A, Isik S, Bayrak G, et al. Using mobile phone text messages to improve insulin injection technique and glycaemic control in patients with diabetes mellitus: a multi-centre study in Turkey. Journal of Clinical Nursing. 2015; 24:1525-1533. DOI: http://10.1111/jocn.12731

8. Bohnet J, Schmitz M, Kamlot S, Abdel-Tawab M. Dosing accuracy and insulin flow rate characteristics of a new disposable insulin pen, Flextouch, compared with Solostar. Journal of Diabetes Science and Technology. 2013; 
7:1021-1026. DOI: http://journals.sagepub.com/doi/ abs/10.1177/193229681300700426

9. Pafili K, Papanas N. The importance of patient compliance with insulin pens: How can anew user-friendly pen help? Expert Opinion on Drug Delivery. 2014; 11:629-632. DOI: http://dx.doi.org/10.1517/17425247.2014.894505 10. Davel H, Berg GI, Allie R, Van der Merwe L. Injection Technique Working Group of the Diabetes Education Society of South Africa (DESSA) Injection technique guidelines for diabetes: sharp and to the point. JEMDSA. 2014; 19:8-13. DOI: http://hdl.handle.net/10520/ EJC151875

11. Farsaei S, Radfar M, Heydaric, Z., Abbasi F, Qorbanie M. Insulin adherence in patients with diabetes: Risk factors for injection omission. Primary Care Diabetes. 2014;8: 338-345. PubMed. DOI: https://doi.org/10.1016/j. pcd.2014.03.001

12. Ji J, Lou Q. Insulin pen injection technique survey in patients with type 2 diabetes in mainland China in 2010. Current Medical Research and Opinion. 2014;30, 1087-1093. DOI: http://dx.doi.org/10.1185/03007995.2014.895711 13. Frid A, Hirsch L, Gaspar R, Hicks D, Kreugel G, Liersch J. The third injection technique workshop in Athens (TITAN). Diabetes \& Metabolism. 2010; 36:19-29. DOI: https://doi.org/10.1016/S1262-3636(10)70003-3 14. Diggle J. Are you FIT for purpose? The importance of getting injection technique right. Journal of Diabetes Nursing. 2014; 18:50-57. DOI: http://www.thejournalofdiabetesnursing.co.uk/media/content/_master/3626/ files/pdf/jdn18-2-50-7.

15. Funnell MM, Brown TL, Childs BP, Haas LB, Hosey GM, Jensen B. National standards for diabetes self-management education. Diabetes Care. 2009;32, 87-94. DOI: http://10.2337/dc14-S144

16. Mitchell VD, Porter K, Beatty SJ. Administration technique and storage of disposable insulin pens reported by patients with diabetes. The Diabetes EducatorJournal.2012;38, 651-658. DOI: http://10.1177/0145721712450921

17. Atukorala K, Sumanasekera D, Wickramasinghe K, Wickramasinghe S. Description of practices related to insulin injection therapy and sharp disposal among patients attending the diabetic clinic. Colombo North Teaching Hospital, Sri Lanka. Endocrine Abstracts. 2015;37: EP325. DOI: http://10.1530/endoabs.37.EP325.

18. Coninck CDE, Frid A, Gaspar R, Hicks D, Hirsch
L, Kreugel G et al. Results and analysis of the 20082009 Insulin Injection Technique Questionnaire survey. Journal of Diabetes. 2010; 2:168-179 PubMed. DOI: http://10.1111/j.1753-0407.2010.00077.x.

19. Aslan U, Korkmaz M. Insulin application information skill levels in diabetic individuals: Errors. DEUHFED. 2015; 8:18-26. (in Turkish)

20. Okuyan B, Sağlam B, Emre E, Demirtunç R, Izzettin F V, Sancar M. Attitude and knowledge of hospitalized patients with type 2 diabetes mellitus towards disposable insulin pens utilization. Marmara Pharmaceutical Journal. 2014; 18:159-163. (in Turkish)

21. Frid A, Hirsch L, Gaspar R, Hicks D, Kreugel G, Liersch J, et al. New injection recommendations for patients with diabetes. Diabetes \& Metabolism. 2010; 36:3-18. 10.1016/S1262-3636(10)70002-1.

22. Rubin RR, Peyrot M, Kruger DF, Travis LB. Barriers to insulin injection therapy: patient and health care provider perspectives. Diabetes Educator Journal. 2009;35 :1014-1022. DOI: http://10.1177/0145721709345773.

23. The National Heart, Lung, and Blood Institute (NHLBI) Calculate Your Body Mass Index (2016). [Cited 27 Mar 2017.] Available from URL: http:/ /www.nhlbi. nih.gov/health/educational/lose_wt/BMI/bmicalc.htm 24. Handelsman Y, Mechanick JI, Blonde L, Grunberger G, Bloomgarden Z, Bray G, et al. American Association of Clinical Endocrinologists Medical Guidelines for Clinical Practice for developing a diabetes mellitus comprehensive care plan. Endocrine Practice. 2011; 17:1-53. 32202. DOI: 10.4158/EP15672.GLSUPPL.

25. Robertson $\mathrm{C}$. The role of the nurse practitioner in the diagnosis and early management of type 2 diabetes. Journal of the American Association of Nurse Practitioners. 2012; 24:225-233. DOI: http://10.1111/j.17457599.2012.00719.x.

26. Ogston-Tuck S. Subcutaneous injection technique: an evidence-based approach. Nursing Standard. 2014; 29:5358. DOI: http://10.7748/ns.29.3.53.e9183.

27. Hunter J. Subcutaneous injection technique. Nursing Standard. 2008; 22:41-44. DOI: http://dx.doi. org/10.7748/ns2008.01.22.21.41.c6418

28. American Diabetes Association, Standards of Medical Care in Diabetes-2017. Journal of Clinical and Applied Research and Education. Diabetes Care. 2017;40(Suppl. 1): S1-S2 DOI: http://10.2337/dc17-S001 
29. Flood B, Henman MC. Case study: hidden complexity of medicines use: information provided by a person with intellectual disability and diabetes to a pharmacist. British Journal of Learning Disabilities. 2015; 43:234-242. DOI: http://10.1111/bld.12121

30. Böhler S, Landgraf W, Schreiber S A. Evaluation of a new disposable insulin pen and injection habits of diabetes patients in everyday clinical practice. $M M W$ - Fortschritte der Medizin. 2010; 151:179-187.
31. Arda H, Kizılc1 S. The Study on the mistakes of individuals with diabetic related to self-injecting insulin. $D i$ yabet, Obezite ve Hipertansiyonda Hemsirelike Forumu Dergisi. 2010;2:1-11. (in Turkish)

32. Blanco M, Hernandez M T, Strauss KW, Amaya M. Prevalence and risk factors of lipohypertrophy in insulin-injecting patients with diabetes. Diabetes \& $M e$ tabolism. 2013; 39:445-453. DOI: http://10.1016/j.diabet.2013.05.006. 